\title{
Changes of Key Climatic Parameters and Flooding in Rivers State, Nigeria
}

Dr. Augusta Ayotamuno B.Tech, MPhil, PhD*

Rivers State University (RSU), Nkpolu - Oroworukwo Port Harcourt, PMB 5080, Nigeria

\section{*Corresponding Author}

Dr. Augusta Ayotamuno B.Tech, MPhil, PhD

\section{Article History}

Received: 07.06.2020

Accepted: 15.06 .2020

Published: 17.06.2020

\begin{abstract}
Key climatic parameters in Rivers State, Nigeria, such as temperature, atmospheric vapour and rainfall spanning a period of 30 years (1988-2018), were collected at the Nigerian Meteorological Agency (NIMET). The data was statistically analysed with the aim of determining the impact of changing climatic parameters on the recently observed flooding events in many of the communities. Results show that there has been a gradual increase in the amount of rainfall with increasing temperature and decreasing atmospheric pressure within the period of study (1988-2018). The studies noted that flooding of many communities in Rivers State and the destruction of their livelihood such as farm lands and markets may have resulted from the increasingly deteriorating climatic parameters over the period of study.
\end{abstract}

Keywords: Climatic elements, Climate change, Flooding and Livelihood.

\section{INTRODUCTION}

Weather is often described as the present atmospheric condition of an area and may include such parameters as rainfall, humidity, temperature, solar radiation, and wind speed; while climate is the mean weather for a given place or region. Climate uses average weather parameters of an area to determine the conditions. That is, weather may change from time to time but that may not necessarily result in climate change. Though both have similar parameters, climate changes are not as readily noticeable. For instance, where there is a significant increase in temperature, this may affect the level of cloudiness as well as the type and amount of precipitation, but may also, on the long run, affect the mean climatic values for these parameters [1].

Another important term in this regard is the issue of climate variability which has to do with the climatic elements of an area changing from its long-term average. Such climatic changes most often than not are not only credited to the aforementioned natural variability, but also human activities. Variation in climate parameters is generally attributed to natural causes. However, because of changes in the earth's climate since the pre-industrial era, some of these changes are now considered attributable to human activities [1].

The increase in surface temperature in the northern hemisphere during the twentieth century is considered greater than for any century in the last 1000 years. Statistics show the global mean surface temperature increased by $0.6 \pm 0.2^{\circ} \mathrm{C}$. The number of hot days in a year increased in many places and the number of cold days decreased in nearly all land areas [2].

Enhanced greenhouse effect is considered the result of human activities that have increased atmospheric concentrations of greenhouse gases and aerosols since the pre-industrial era. The atmospheric concentrations of key greenhouse gases include carbon dioxide $(\mathrm{CO} 2)$, methane $(\mathrm{CH} 4)$, nitrous oxide $(\mathrm{N} 2 \mathrm{O})$ and ozone $(\mathrm{O} 3)$ [3].

In Nigeria and particularly Rivers State, the atmospheric concentrations of key greenhouse gases may have reached their highest recorded levels in the 2000's, primarily due to the combustion of fossil fuels in the form of illegal

Copyright @ 2020: This is an open-access article distributed under the terms of the Creative Commons Attribution license which permits unrestricted use, distribution, and reproduction in any medium for non commercial use (NonCommercial, or CC-BY-NC) provided the original author and source are credited. 
refineries scattered all along the creeks and improper land-use changes where building are erected even on reclaimed wet lands and natural flood paths.

The entire nation of Nigeria and indeed Rivers State at the various geographical regions have experienced a lot of climatic changes [4]. Flooding in urban areas in Rivers State is not only as a result of heavy rainfall and extreme climatic events but also on a number of other factors such as changes in the built-up areas themselves. The city of Port Harcourt, particularly, has experienced a lot of changes which is evidenced in a previous paper by Ayotamuno and Ekaka [5]. The built up areas, due to urbanization, comes with a lot of challenges in relation to movement of flood waters. For instance, natural flow of floodwaters are diverted or slowed down by roads and pavements, thus obstructing natural channels. This problem would have been resolved by building drains that ensure that water moves to rivers more rapidly than it did under natural conditions. Large-scale urbanization and population increases have led to large numbers of people, especially the poor, settling and living in floodplains in and around urban areas.

In a previous paper by Ayotamuno \& Gobo [6] on the present state of land use and land cover in Port Harcourt and how it has been affected by climatic elements, they observed that there have been climatic deviations in rainfall and temperature values and very obvious changes in the spatial pattern of land use and land cover between 1984 to 2014 . They noted that Built-Up areas showed an increase from $16.50 \%$ in 1984 to $51.38 \%$ in 2014; and that a lot of development has taken place using up most of the Gallery Forest, Vegetation area and the Water Bodies. Development of Built-Up area needs to be controlled so that all of the vegetation is not used up because the city needs some vegetation to allow the city breath.

It is important to also recall that in an earlier research has been carried out by [7], Diobu GRA Phase II in Port Harcourt, over time changed gradually from a low density to a high density area, and indeed from a quiet residential area to an area with a high concentration of road traffic and commercial enterprises, ranging from banks, offices, supermarkets, hotels and fast-food enterprises. Over the years, due to a lack of enforcement of the building regulations, additional houses or house extensions were built, leaving little or no open space. Today, most compounds and plots have no service space and no gardens. This densification and loss of open space is also evident in many other neighbourhoods.

The clear message emerging thus far is that urban flooding is becoming an increasingly severe and more frequent problem for the urban dwellers due to local human factors such as urban growth, the occupation of floodplains and the lack of attention to waste management and negligence by those concerned in the construction and maintenance of drainage channels which are also aggravating the flooding problem. Particularly problematic is the unwillingness of government at all levels to engage in the provision of integrated drainage systems in informal settlements, which are often regarded as being outside accepted urban regulation and planning systems. This study therefore wish to examine changes in key climatic parameters that may have impacted on flooding in Rivers State given the many other lingering environmental management problems over the years. The objectives of study are:

(1) To study some key climatic parameters in Rivers State in the last 30yrs.

(2) Ascertain if there have been changes in the climatic elements and the factors that led to them during the period of study.

(3) To examine the challenges caused by the climatic changes and the effect on the urban environment, including flooding.

\section{The Study Area and Weather Data Collection}

Rivers State is one of the 36 states of Nigeria. According to census data released in 2006, the state has a population of 5,198,716, making it the sixth-most populous state in the country. The study area lies within the Niger Delta which features tropical monsoon with two distinct seasons; the rainy season which is usually lengthy and heavy and the dry season which is normally very short. Only the months of December and January truly qualify as the dry season months. In Port-Harcourt, there is a well-defined pattern of the monthly rainfall, described as bimodal. The harmattan which climatically influences many cities in West Africa is less pronounced in the study area. Temperatures throughout the year in the city are relatively constant, showing little variation throughout the course of the year [8].

Rainfall is adequate for all year-round crop production in the State. The duration of the wet season is not less than 330 days, of which a great number is rainy days (days with $250 \mathrm{~mm}$ or more of rain). For Port Harcourt, the rainy days are about 182 . Mean maximum monthly temperatures range from $28^{\circ} \mathrm{C}$ to $33^{\circ} \mathrm{C}$, while the mean minimum monthly temperatures are in the range of $17^{\circ} \mathrm{C}$ to $24^{\circ} \mathrm{C}$.

The mean monthly temperature is in the range of $25^{\circ} \mathrm{C}$ to $28^{\circ} \mathrm{C}$. The mean annual temperature for the State is $26^{\circ} \mathrm{C}$. The hottest months are February to May. The difference between the dry season and wet season temperatures is only about $2^{\circ} \mathrm{C}$. Relative humidity is high in the State throughout the year and decreases slightly in the dry season. 
The character of Rivers State relief, drainage and geology poses much problem to resource exploitation and economic development. Other ecological problems include severe beach erosion associated with sea level rise due to global climatic change; annual inundation by river floods; salty soils especially in the dry season; too much leaching of soil fertility due to excessive rainfall; and susceptibility of settle merit sites along the creeks to creek erosion. Aisuebeogun [9].

Weather data, particularly Atmospheric pressure, temperature, humidity, sunshine hours, etc, in the last 30year (1988-2018) was collected from the Nigerian Meteorological Agency [10]. These were statistically analysed with information obtained from in-depth desk top literature studies. These were corroborated with photographs taken in recent flooded neighbourhoods across Port Harcourt.

\section{Results of some key climatic parameters in Rivers State}

Below are some graphs and pictures of various parts of the Rivers State affected by flooding and climate change.

In Table 1, the yearly minimum mean temperature was $27.6^{\circ} \mathrm{C}$ in 1992 and maximum temperature was $36.4^{0} \mathrm{C}$ in 2006, a period spanning 14 years. There appears to be a similar temperature reading in all the years with exception of years 2007, 2010 and 2014 (32.0, 32.0, and 32.1-Degree Celsius).

Table-1a: Descriptive Statistics for Yearly Temperature

\begin{tabular}{|l|r|r|r|r|r|r|r|r|r|r|r|r|r|}
\hline Parameters & $\mathbf{1 9 8 8}$ & $\mathbf{1 9 8 9}$ & $\mathbf{1 9 9 0}$ & $\mathbf{1 9 9 1}$ & $\mathbf{1 9 9 2}$ & $\mathbf{1 9 9 3}$ & $\mathbf{1 9 9 4}$ & $\mathbf{1 9 9 5}$ & $\mathbf{1 9 9 6}$ & $\mathbf{1 9 9 7}$ & $\mathbf{1 9 9 8}$ & $\mathbf{1 9 9 9}$ & $\mathbf{2 0 0 0}$ \\
\hline Mean & 31.3 & 31.3 & 31.3 & 31.0 & 31.2 & 31.4 & 31.3 & 31.6 & 31.3 & 31.3 & 31.9 & 31.0 & 31.5 \\
\hline Standard Error & 0.5 & 0.6 & 0.7 & 0.4 & 0.6 & 0.5 & 0.6 & 0.5 & 0.5 & 0.5 & 0.6 & 0.4 & 0.6 \\
\hline Median & 31.4 & 31.5 & 31.3 & 31.3 & 31.7 & 32.0 & 32.0 & 31.7 & 32.1 & 31.0 & 31.5 & 31.3 & 31.7 \\
\hline Standard Deviation & 1.9 & 1.9 & 2.3 & 1.4 & 2.2 & 1.8 & 2.1 & 1.9 & 1.8 & 1.8 & 2.2 & 1.4 & 2.0 \\
\hline Sample Variance & 3.6 & 3.8 & 5.4 & 2.0 & 5.0 & 3.2 & 4.2 & 3.5 & 3.4 & 3.4 & 4.8 & 1.9 & 3.8 \\
\hline Kurtosis & -1.2 & -0.3 & -0.1 & -1.1 & -1.1 & -0.9 & -1.1 & -0.9 & -1.2 & 0.3 & -1.0 & -1.6 & -1.1 \\
\hline Skewness & 0.1 & 0.2 & 0.4 & -0.4 & -0.2 & -0.4 & -0.5 & 0.2 & -0.6 & 0.5 & 0.4 & -0.3 & 0.1 \\
\hline Range & 5.7 & 6.5 & 7.8 & 4.2 & 6.8 & 5.6 & 6.0 & 6.1 & 5.4 & 6.5 & 6.1 & 3.8 & 5.8 \\
\hline Minimum & 28.9 & 28.6 & 27.9 & 28.6 & 27.6 & 28.5 & 27.9 & 28.9 & 28.1 & 28.6 & 29.3 & 28.8 & 28.8 \\
\hline Maximum & 34.6 & 35.1 & 35.8 & 32.9 & 34.4 & 34.1 & 33.9 & 35.0 & 33.5 & 35.1 & 35.4 & 32.7 & 34.5 \\
\hline
\end{tabular}

Table-1a: Continuation of Descriptive Statistics for Yearly Temperature

\begin{tabular}{|c|c|c|c|c|c|c|c|c|c|c|c|c|c|c|c|c|c|c|}
\hline Parameters & $\underset{\sim}{\stackrel{乛}{\Im}}$ & $\widetilde{\S}$ & 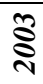 & $\underset{\sim}{\stackrel{乛}{*}}$ & 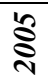 & ฐั & $\widehat{\overbrace{}}$ & 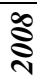 & 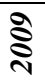 & $\underset{\sim}{\stackrel{乛}{*}}$ & $\bar{\sim}$ & $\underset{\sim}{\stackrel{\sim}{\sim}}$ & 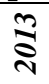 & $\frac{7}{\sim}$ & $\frac{10}{8}$ & จำ & $\stackrel{\widehat{)}}{\sim}$ & $\stackrel{\infty}{\Omega}$ \\
\hline Mean & $\frac{m}{m}$ & $\frac{\dot{m}}{m}$ & $\underset{m}{m}$ & $\frac{n}{n}$ & $\stackrel{\varphi}{m}$ & $\frac{\rho}{m}$ & 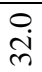 & $\stackrel{\infty}{\infty}$ & 宛 & $\underset{\text { r }}{\stackrel{\circ}{ }}$ & 㲾 & $\underset{m}{m}$ & $\frac{m}{m}$ & $\vec{n}$ & $\frac{\dot{m}}{\dot{m}}$ & $\vec{m}$ & $\underset{m}{m}$ & m \\
\hline Standard Error & $\stackrel{0}{0}$ & $\tilde{n}$ & $\ddot{n}$ & $\stackrel{0}{0}$ & $\dddot{n}$ & $\dddot{n}$ & $\tilde{n}$ & $\dddot{n}$ & $\stackrel{n}{0}$ & $\stackrel{0}{0}$ & $\stackrel{n}{0}$ & $\stackrel{0}{0}$ & $\stackrel{n}{0}$ & $\stackrel{+}{\circ}$ & $\begin{array}{l}0 \\
0\end{array}$ & $\ddot{0}$ & $\stackrel{0}{0}$ & $\stackrel{+}{0}$ \\
\hline Median & $\frac{\dot{j}}{\dot{m}}$ & $\begin{array}{l}\text { ํ. } \\
\text { mे }\end{array}$ & $\vec{i}$ & $\frac{n}{m}$ & กָ & 올 & ָ̃ & กิ & ָ̃ & $\frac{\infty}{\dot{m}}$ & ָ̃ & $\overrightarrow{\text { ते }}$ & $\frac{n}{n}$ & ñ & กָ & $\frac{0}{\dot{m}}$ & $\frac{0}{\dot{m}}$ & $\stackrel{0}{m}$ \\
\hline Standard Deviation & $\stackrel{\circ}{i}$ & I & $\stackrel{\infty}{-}$ & $\stackrel{\circ}{i}$ & $\stackrel{\infty}{-}$ & $\stackrel{\infty}{\infty}$ & $\stackrel{\infty}{-}$ & I & $\stackrel{\infty}{-}$ & $\overrightarrow{\mathrm{i}}$ & $\stackrel{\infty}{-}$ & $\stackrel{\circ}{i}$ & $\stackrel{\infty}{-}$ & $\stackrel{n}{n}$ & $\stackrel{9}{-}$ & $\stackrel{+}{i}$ & $\vec{i}$ & $\stackrel{n}{-}$ \\
\hline Sample Variance & ले & $\stackrel{\circ}{\circ}$ & $\vec{m}$ & $\hat{)}$ & $\ddot{n}$ & $\vec{m}$ & $\vec{m}$ & $\widehat{\overbrace{}}$ & $\stackrel{\sim}{m}$ & $\stackrel{+}{+}$ & $m$ & $\stackrel{\infty}{\infty}$ & $\vec{m}$ & $\tilde{n}$ & $\begin{array}{l}\infty \\
\dot{m}\end{array}$ & $\stackrel{0}{0}$ & $\stackrel{\Upsilon}{\forall}$ & $\stackrel{\nabla}{\sim}$ \\
\hline Kurtosis & $\stackrel{0}{+}$ & $\stackrel{+}{\rightarrow}$ & $\stackrel{?}{\rightarrow}$ & n? & $\underset{7}{\longrightarrow}$ & $\stackrel{n}{\rightarrow}$ & $\frac{\sim}{\top}$ & $\stackrel{+}{\circ}$ & $\stackrel{n}{n}$ & $\stackrel{\infty}{i}$ & $\frac{+}{i}$ & $\stackrel{\sim}{\top}$ & $\frac{n}{1}$ & $\stackrel{+}{0}$ & $\stackrel{+}{+}$ & i. & $\overrightarrow{0}$ & $\stackrel{0}{0}$ \\
\hline Skewness & ָ̦ & $\vec{i}$ & 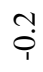 & ?? & $\stackrel{+}{i}$ & 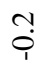 & $\stackrel{\sim}{0}$ & $\tilde{0}$ & ?n & $\stackrel{0}{0}$ & $\stackrel{+}{\dot{\varphi}}$ & $\vec{i}$ & $\overrightarrow{0}$ & $\underset{1}{\sim}$ & $\stackrel{+}{0}$ & $n$ & $\stackrel{+}{0}$ & $\stackrel{0}{0}$ \\
\hline Range & $\tilde{n}$ & min & $\vec{n}$ & $\underset{0}{+}$ & $n$ & $\stackrel{m}{n}$ & $\stackrel{q}{\dot{\nabla}}$ & $\vec{i}$ & $\stackrel{9}{i}$ & $\begin{array}{l}0 \\
\dot{n}\end{array}$ & $\begin{array}{l}0 \\
i\end{array}$ & in & $\stackrel{\infty}{+}$ & $\stackrel{\vartheta}{\dot{\gamma}}$ & $\begin{array}{l}\dot{r} \\
\dot{n}\end{array}$ & $\stackrel{+}{r}$ & $\stackrel{\circ}{r}$ & $\stackrel{\bullet}{+}$ \\
\hline Minimum & $\stackrel{\infty}{\Delta}$ & $\begin{array}{l}\infty \\
\dot{\infty} \\
\stackrel{d}{0}\end{array}$ & $\begin{array}{l}0 \\
\stackrel{2}{े}\end{array}$ & $\begin{array}{l}n \\
\stackrel{\sim}{N}\end{array}$ & $\begin{array}{l}0 \\
\dot{0} \\
\sim\end{array}$ & 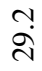 & 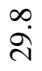 & $\begin{array}{l}\infty \\
\stackrel{\sim}{े}\end{array}$ & 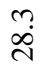 & 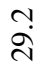 & $\begin{array}{l}\hat{\jmath} \\
\dot{\sim}\end{array}$ & $\stackrel{\vec{d}}{\vec{d}}$ & $\begin{array}{l}\infty \\
\infty \\
\infty\end{array}$ & $\begin{array}{l}\stackrel{\rho}{0} \\
\stackrel{\sim}{0}\end{array}$ & $\begin{array}{l}n \\
\stackrel{n}{0}\end{array}$ & $\begin{array}{l}0 \\
\stackrel{2}{0}\end{array}$ & $\stackrel{i}{\grave{d}}$ & 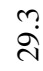 \\
\hline Maximum & $\stackrel{m}{m}$ & $\vec{m}$ & $\stackrel{\sim}{\stackrel{m}{m}}$ & $\begin{array}{l}\dot{0} \\
\dot{n}\end{array}$ & $\vec{m}$ & $\begin{array}{l}\dot{+} \\
\dot{m}\end{array}$ & 官 & $\stackrel{n}{n}$ & $\stackrel{\sim}{\stackrel{N}{m}}$ & $\stackrel{\vec{m}}{\dot{m}}$ & $\dot{m}$ & $\begin{array}{l}\dot{b} \\
\dot{m}\end{array}$ & $\begin{array}{l}\dot{m} \\
\dot{m}\end{array}$ & $\begin{array}{l}\dot{0} \\
\dot{m}\end{array}$ & $\dot{m}$ & $\underset{\dot{m}}{\dot{\theta}}$ & $\begin{array}{l}\infty \\
m \\
m\end{array}$ & $\dot{m}$ \\
\hline
\end{tabular}


But in Table 2 the maximum monthly temperature was $36.4^{0} \mathrm{C}$ in the month of February while the minimum temperature was $27.6{ }^{0} \mathrm{C}$ in the month of August. Also, in Table 2, it would be observed that the mean temperatures for the month of January, March and April (33.1,33.3,32.5-Degree Celsius) are about the same except for the months of August, September and July which for obvious reasons recorded lower temperature trends (28.9,29.1,29.7-Degree Celsius).

Table-2: Descriptive Statistics for monthly temperature (1988-2018)

\begin{tabular}{|c|c|c|c|c|c|c|c|c|c|c|c|c|}
\hline Parameters & Jan & $\mathrm{Feb}$ & March & April & May & June & July & Aug & Sept & $O c t$ & Nov & $D e c$ \\
\hline Mean & 33.1 & 34.2 & 33.3 & 32.5 & 31.8 & 30.4 & 29.1 & 28.9 & 29.7 & 30.6 & 32.0 & 32.7 \\
\hline Standard Error & 0.1 & 0.2 & 0.2 & 0.1 & 0.1 & 0.1 & 0.1 & 0.1 & 0.1 & 0.1 & 0.1 & 0.2 \\
\hline Median & 32.9 & 34.1 & 33.1 & 32.5 & 31.9 & 30.3 & 29.1 & 28.9 & 29.7 & 30.7 & 32.0 & 32.7 \\
\hline Mode & 32.8 & 34.1 & 32.7 & 33.1 & 31.6 & 30.6 & 28.9 & 28.6 & 29.4 & 30.1 & 32.0 & 32.1 \\
\hline $\begin{array}{l}\text { Standard } \\
\text { Deviation }\end{array}$ & 0.7 & 0.9 & 0.9 & 0.8 & 0.6 & 0.7 & 0.5 & 0.6 & 0.6 & 0.6 & 0.6 & 0.9 \\
\hline Sample Variance & 0.6 & 0.9 & 0.8 & 0.7 & 0.4 & 0.5 & 0.3 & 0.3 & 0.3 & 0.4 & 0.4 & 0.9 \\
\hline Kurtosis & 0.6 & 0.0 & 0.9 & 8.8 & 8.3 & 8.8 & -0.2 & -0.2 & -0.6 & 1.0 & -0.8 & -0.5 \\
\hline Skewness & 0.8 & 0.2 & 1.2 & -2.0 & -2.0 & 2.3 & -0.3 & -0.2 & 0.3 & 0.4 & 0.0 & -0.1 \\
\hline Range & 3.1 & 4.0 & 3.6 & 4.9 & 3.8 & 3.9 & 1.9 & 2.3 & 2.1 & 3.0 & 2.3 & 3.7 \\
\hline Minimum & 31.7 & 32.3 & 32.2 & 29.2 & 29.2 & 29.3 & 27.9 & 27.6 & 28.8 & 29.4 & 30.8 & 30.7 \\
\hline Maximum & 34.9 & 36.4 & 35.8 & 34.1 & 33.0 & 33.2 & 29.9 & 29.9 & 30.9 & 32.3 & 33.2 & 34.4 \\
\hline
\end{tabular}

Furthermore, in Figure 1 the total least yearly minimum temperatures recorded was $237.9^{0} \mathrm{C}$ in 2001 , while the highest yearly temperature was $277.6^{\circ} \mathrm{C}$ in 2010. In other words, within a time period of 9 years temperature fluctuations around Port Harcourt was as much as $40^{\circ} \mathrm{C}$. The fact remains that the temperatures around Rivers State axis has been on an incremental trend in the last 10 years or more, not least because of the excessive anthropogenic activities, including artisanal refineries and gas flaring, that may have greatly depleted the ozone layer projected into the space.

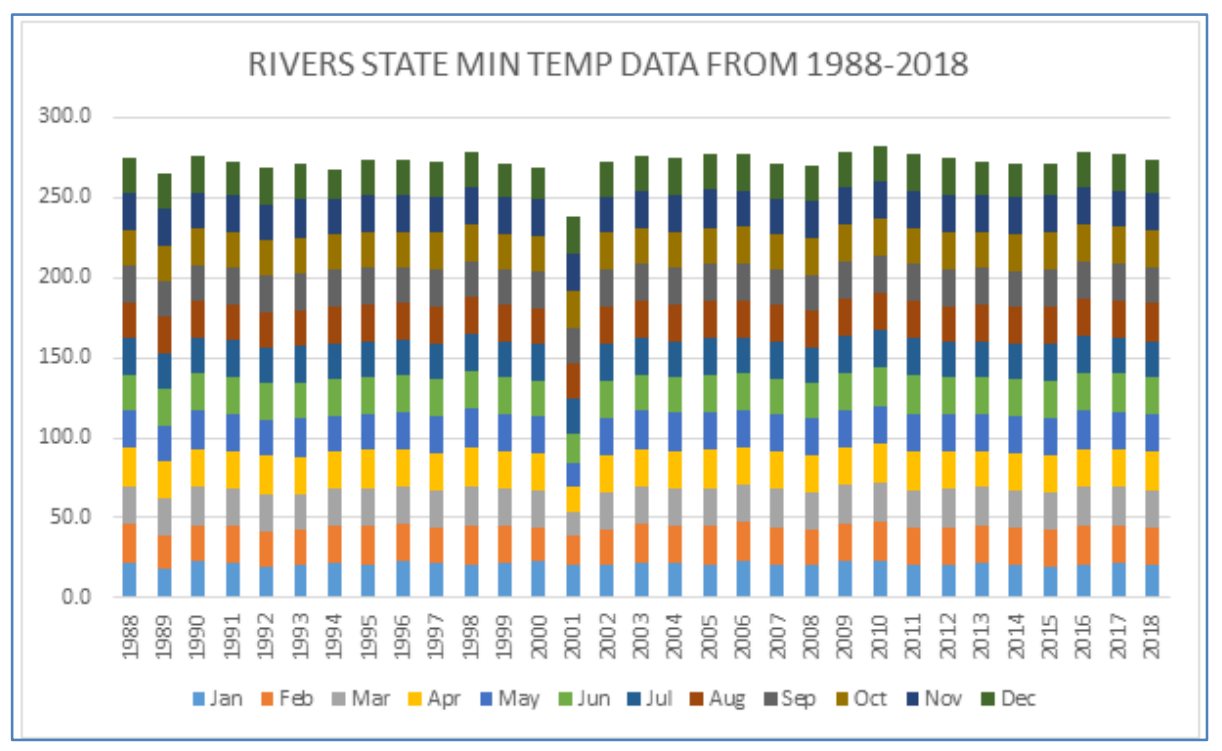

Fig-1: Bar Chart of the Various Years as well as the Monthly Min Temperature from 1988 - 2018

Data from NIMET (Fig. 2), showed that from 1988-2018 the highest atmospheric pressure was $11.6 \mathrm{hPa}$ in 1992 while the lowest was $10.4 \mathrm{hPa}$ in 2008 . In order words for about 16 years the atmospheric pressure has been on the decline. But from 2008-2018, it only slightly increased from $10.8 \mathrm{hP}$ to $10.9 \mathrm{hP}$, a margin of just $0.1 \mathrm{hP}$ in about $10 y e a r s$. The decreasing atmospheric pressure may be due to a number of factors including increasing temperature and excessively building of the environment over the years. 


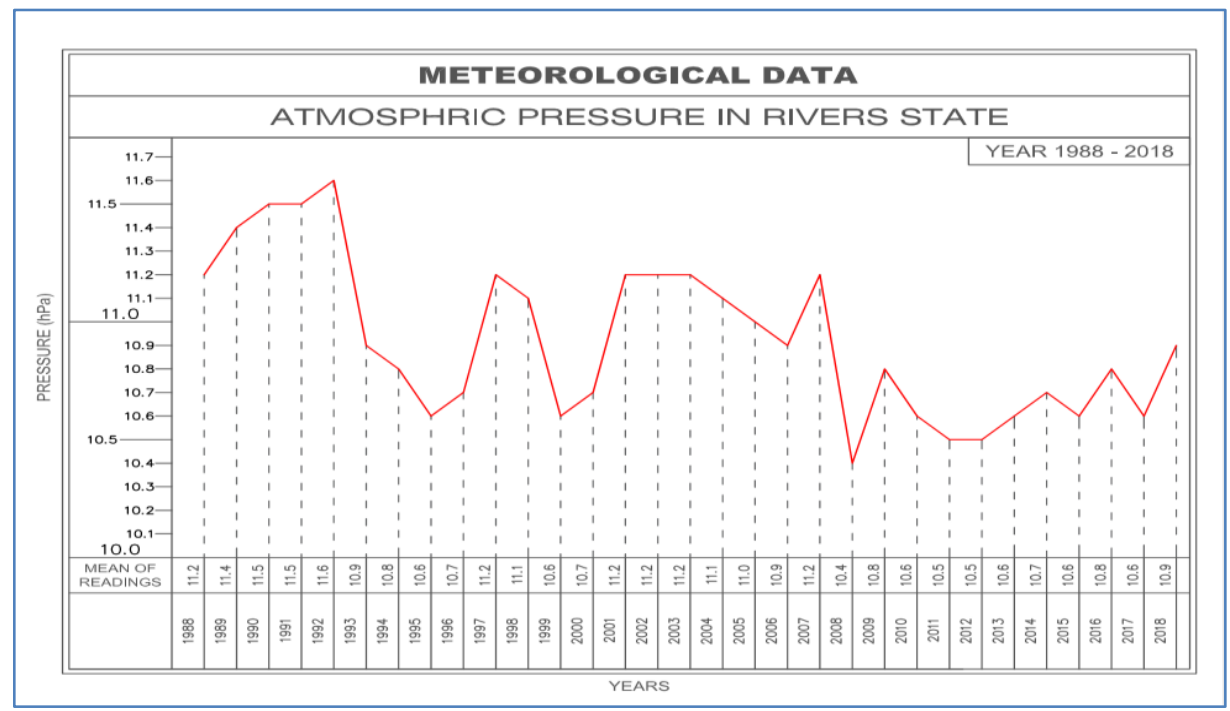

Fig-2: Yearly Atmospheric Temperature in Rivers State from 1988 - 2018

Within the period of review (1988-2018), the highest yearly rainfall happened in 2007 (2790mm), and the least in $2011(1749.2 \mathrm{~mm}$ ) as seen in (Figs. 3 and 4). Also, the highest monthly was $578.1 \mathrm{~mm}$ in August in 1990 and the least was $2.4 \mathrm{~mm}$ in January in 2008 . But the highest average rainfall, $349.20 \mathrm{~mm}$, within the 30 -year period of study, was in the month of September.

On the whole, there has been a gradual increase in the amount of rainfall with increasing temperature and decreasing atmospheric pressure within the period of study (1988-2018).

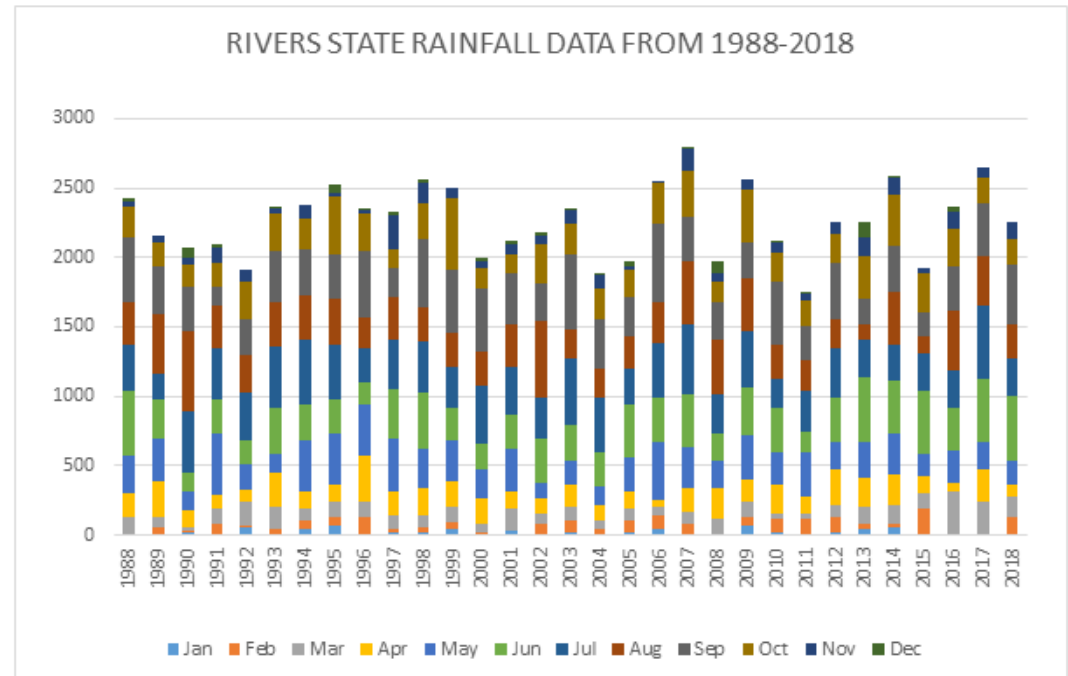

Fig-3: Bar Chart showing the various years as well as the monthly Rainfall from 1988 - 2018

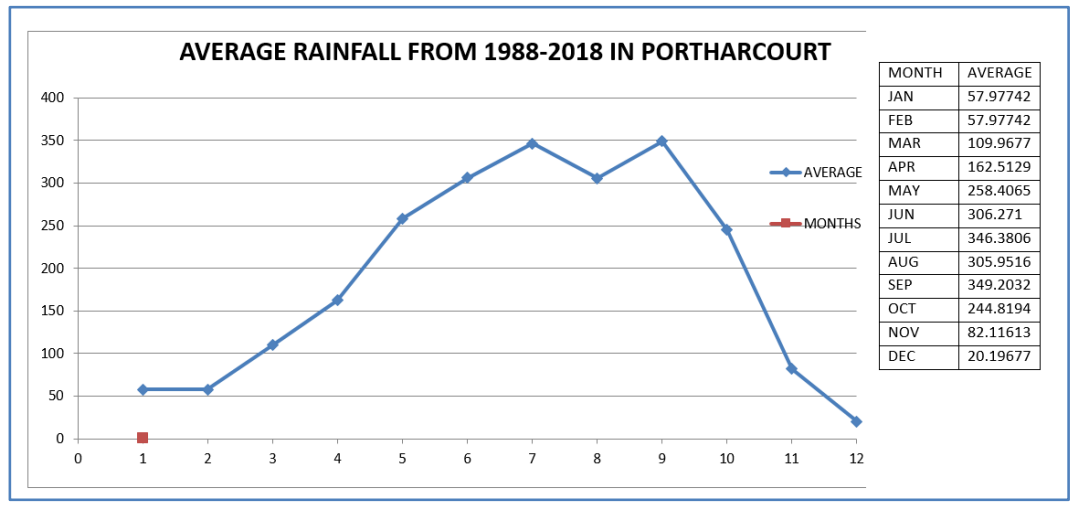

Fig-4: Average Monthly Rainfall from 1988 - 2018 


\section{Challenges of Climate Change in Rivers State}

The consequences of this climate inconsistency and change in Rivers State has posed severe hardship to the lives of the masses and their livelihoods as well as to the state's socioeconomic development. Particularly, climate change resulting from possible increasing temperature, as the years go by, may have resulted in the current heavy precipitation events being observed in Rivers State. But heavy rainfall does not automatically result to floods, but it increases the potential for them. And even moderate amounts of rainfall can cause serious damage, particularly in places like Rivers State where urban flooding is on the rise.

Flooding also brings contamination and disease. Floodwaters have been observed to cause raw sewage, leaked toxic chemicals, and runoff from hazardous waste sites and factory farms, many of which are located around the Transamadi industrial area of Port Harcourt. They pollute drinking water supplies and cause eye, ear, skin, and gastrointestinal infections. When floodwaters recede, bacteria and mold may remain, increasing rates of respiratory illnesses, such as asthma. Flooding has contributed to the virtual uproot of whole communities in some suburbs resided by the very poor and low income earners in Rivers State.

There is no doubt that the recent floods in Rivers State are climate related and are expected to increase in frequency and intensity in the long-run. During such times which comes with heavy wind storms, roofs of buildings are removed, roads are submerged with water, thus totally impeding human and vehicular movement (see Figs 5, 6, 7, 8, 9.). Sometimes children on the path of the flood may be drowned and vehicles and small buildings on its path of flow damaged.

Farm land are also affected with crops completely submerged resulting in very little or no yield at all. This situation, most often than not, leads to poor crop harvest, food shortage and indeed starvation. Flooding in Rivers State also affects infrastructure including roads, bridges and pipelines, as well as electricity and telephone lines. These structures are in the process weakened and sometimes fall to the ground during heavier rainfall and windy storms; and thus, impacting on the social, economic and commercial activities of the affected communities and indeed Rivers State.

The climatic change in Rivers State which may have resulted from increasing temperature over the years may have increased the number of mosquitoes and certainly malaria diseases in the affected communities. As the temperatures continue to increase in the coming years development time of pathogens in vectors will reduce and this will increase the potential transmission to humans. Below are pictures of flooded neighbor hoods in Rivers State.

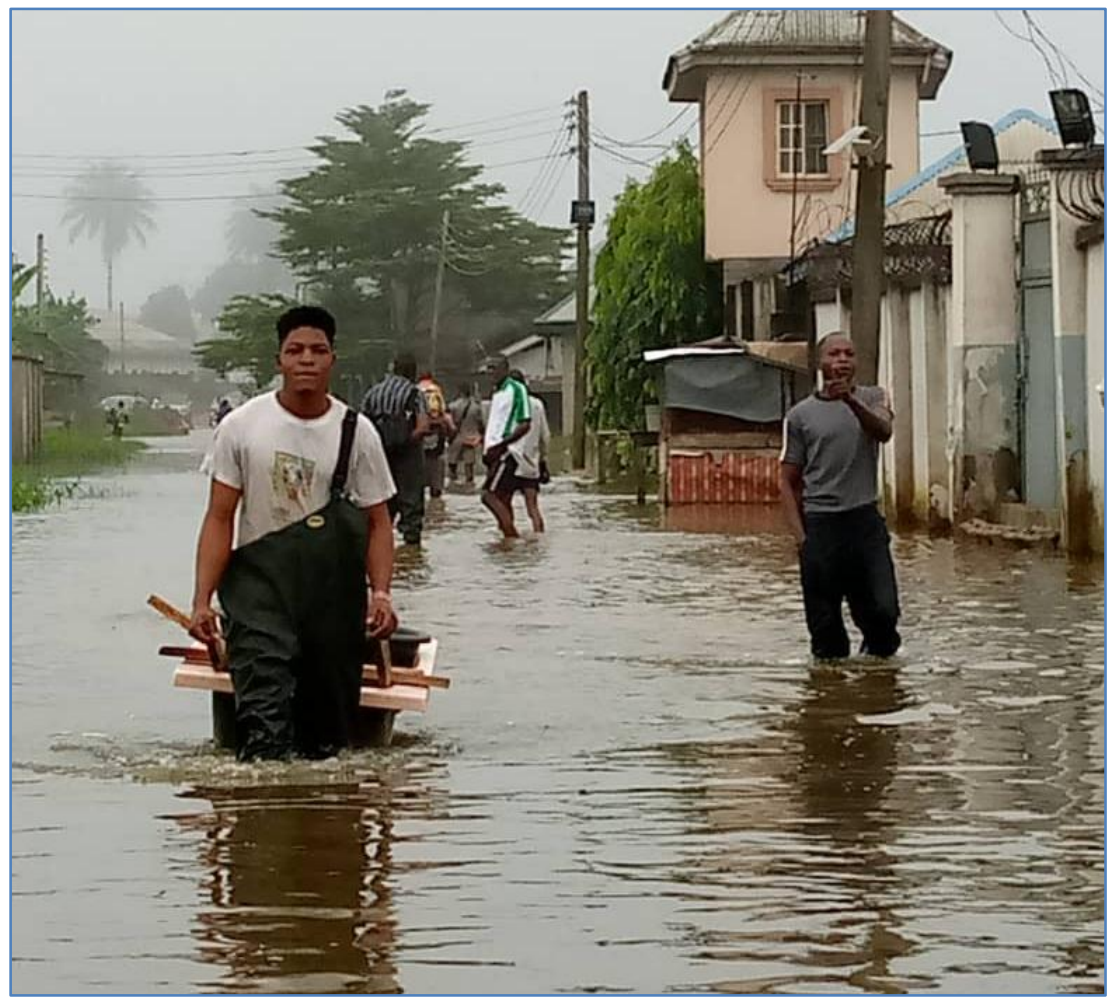

Fig-5: Flooded Neighbourhood in Eneka Obio -Akpor, 2019

Source: Author's Field Work 


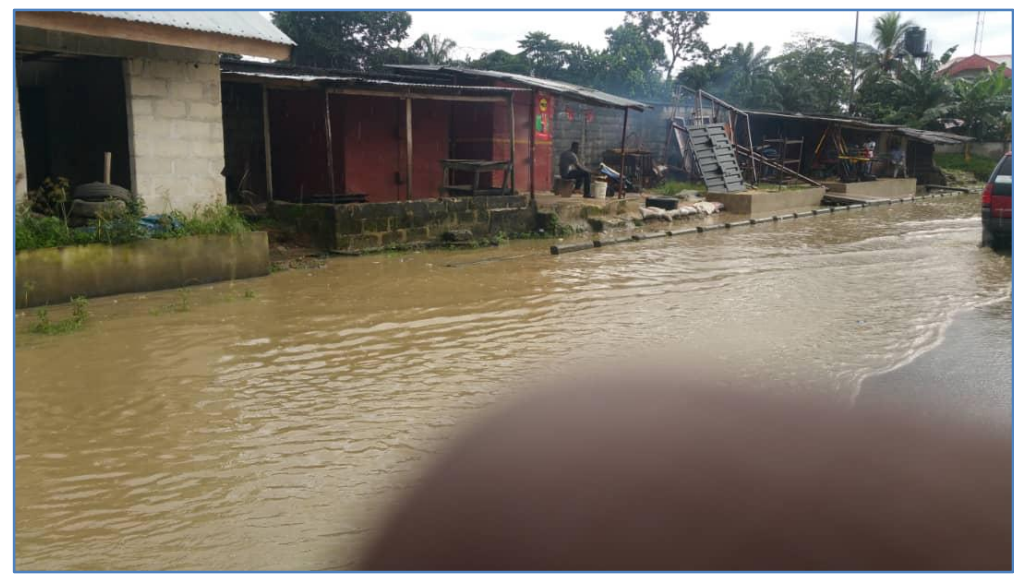

Fig-6: Flooded Neighbourhood in Port Harcourt, 2019 Source: Author's Field Work

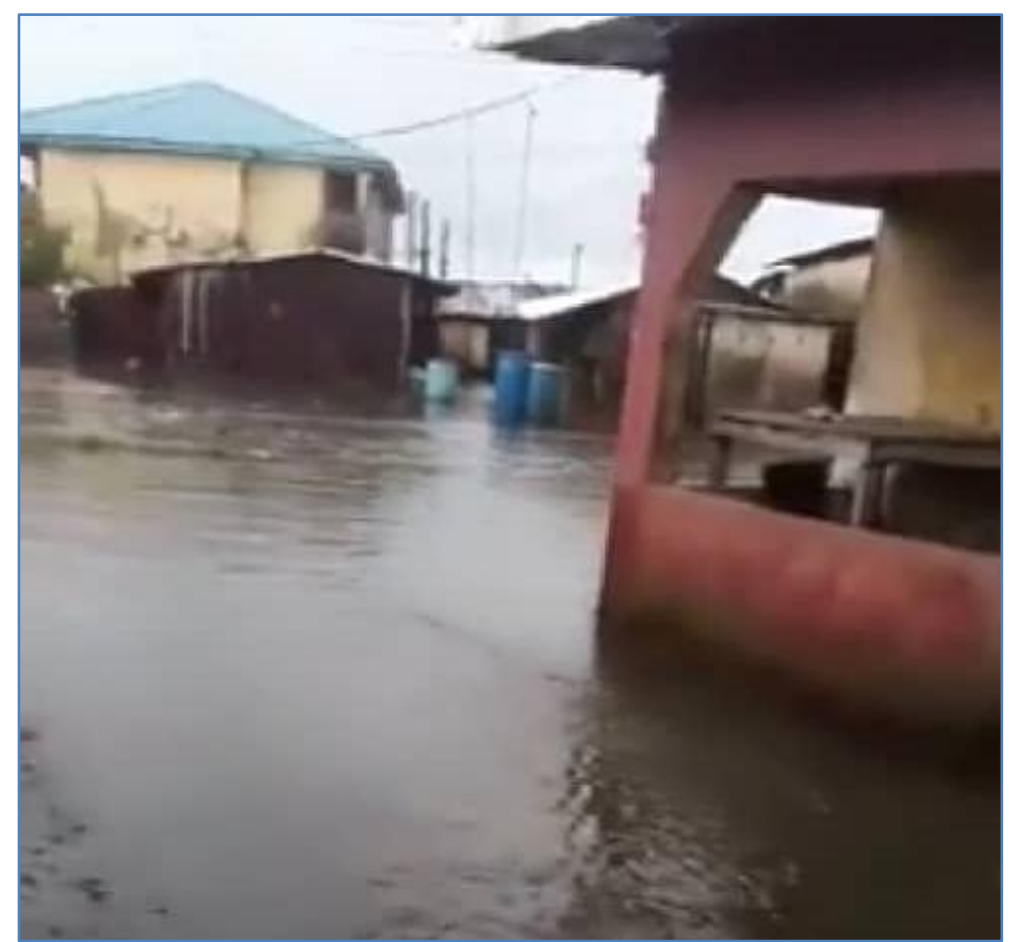

Fig-7: Flooded Neighbourhood in Eneka Obio -Akpor, 2019 Source: Author's Field Work

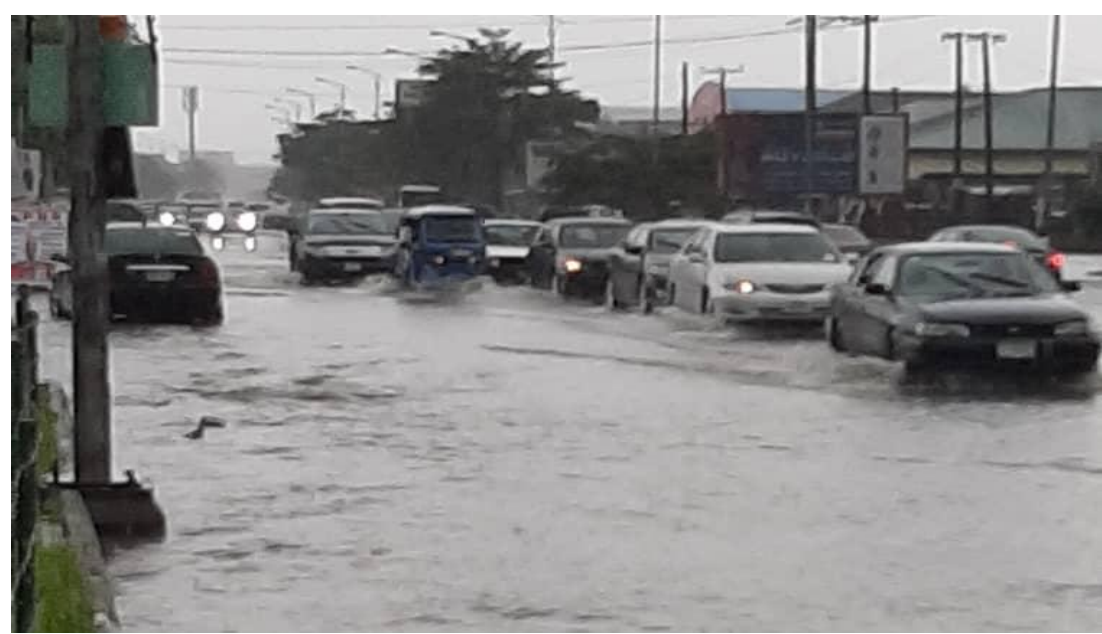

Fig-8: Flooded Neighbourhood Market Junction Rumuomasi in Port Harcourt, 2019 Source: Author's Field Work 


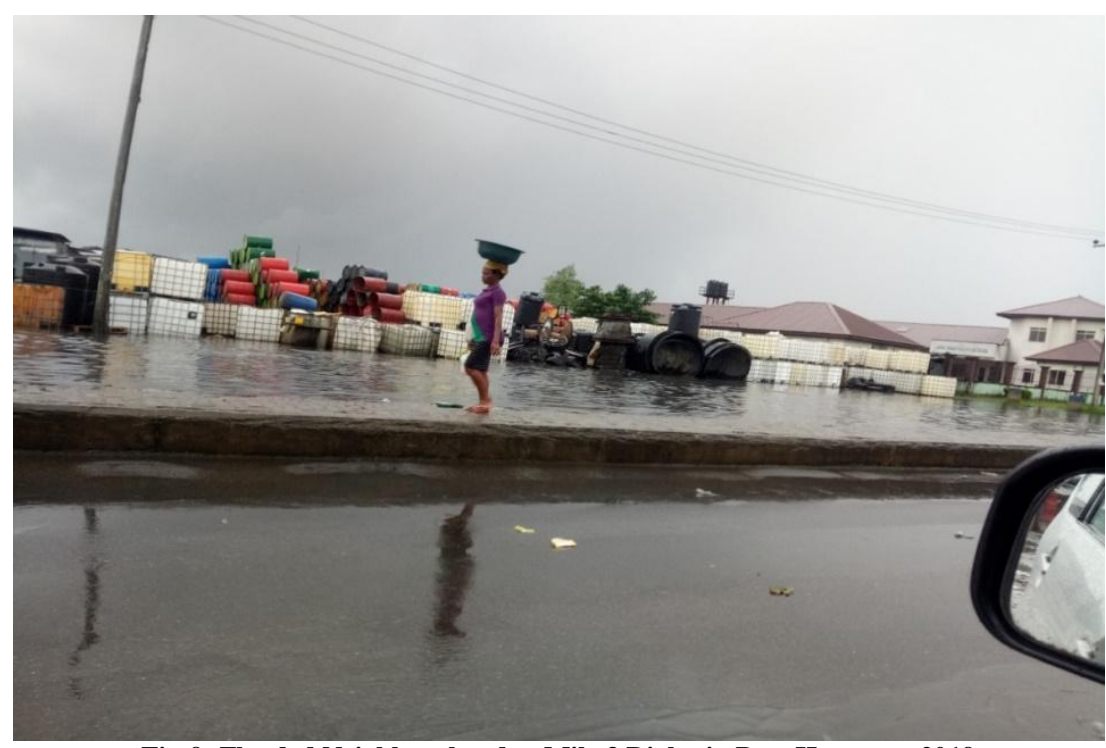

Fig-9: Flooded Neighbourhood at Mile 3 Diobu in Port Harcourt, 2019 Source: Author's Field Work

\section{CONCLUSION}

Changes in key climatic parameters such as temperature, atmospheric pressure and rainfall in the last 30 years (1988-2018) may have resulted in the increasing heavy flooding recently experienced in many communities in Rivers State, Nigeria. The flooding causes roads and even farm land to be submerged under water, thus impeding movement, both human and vehicular, and destroying agriculture. Infrastructure including roads, bridges, water supply, electricity and telephone lines are negatively impacted. The risk of flooding is more pronounced in poor and low-income communities as a result of little investment in housing and infrastructure by successive governments in Rivers State over the years.

\section{REFERENCES}

1. National Aeronautics and Space Administration. (NASA, 2005). Excerpts from web page.

2. Intergovernmental Panel on Climate Change (IPCC). (2001). Impacts, Adaptation and Vulnerability, Contribution of Working Group II to the Third Assessment Report of the Intergovernmental Panel on Climate Change, Cambridge University Press, Cambridge, 1- 1,032

3. Pidwirny, M. (2006). 'Atmospheric Composition'. Fundamentals of Physical Geography, $2^{\text {nd }}$ Edition.

4. Oriji, C.C. (2015). What to do About Climate Change-Caused Flooding and the Associated Diseases in Rivers State of Nigeria. - Global Journal of Human - Social Science, Geography, Geo-Sciences, Environmental Science and Disaster Management, 15(4):29 -34

5. Ayotamuno. A., \& Ekaka, E. N. (2017). How has Population Growth and Demand for Housing Affected Land Use in Port Harcourt, Nigeria. Global Educational Research Journal. 5(3), 563-578, Spring Journals. USA

6. Ayotamuno. A., \& Gobo A.E. (2016). The Effect of Climate on Land Use and Land Use Cover in Spatial Development in Port Harcourt, Nigeria. Climate Change, The International Journal. Discovery Publication, 2(7). 223 -246. UK

7. Ayotamuno, A., Gobo, A.E., \& Owei O.B. (2010). The Impact of Land Use Conversion on a Residential District in Port Harcourt, Nigeria. Environment \& Urbanization, an International Journal. International Institute for Environment and Development (IIED). 20(10), 259 - 264. UK

8. Offodile, M. E. (2002). Groundwater study and development in Nigeria. Mecon Geology and Engineering Services Limited, (2); 239-255.

9. Aisuebeogun, A. (1995). The Port Harcourt Region: Landforms Characteristics of the Environment. Journal of Geographic Thought, 1(1), $10-14$

10. Nigerian Meteorological Agency. (NIMET, 2019). Documents. 